\title{
Design of an Indirect Dryer with Coupling of Solar Collectors and its Thermal Characterization by Drying the Mint Leaves (Mentha spicate)
}

\author{
Margarita Castillo Téllez*1, Beatriz Castillo-Téllez², Alberto Mejía Pérez Gerardo², \\ Rachid Marzoug ${ }^{2}$, Diana C. Mex Álvarez ${ }^{1}$
}

\begin{abstract}
Man has used solar energy to dry perishable products for many years, managing to preserve a wide variety of foods naturally; drying is a method that highly respects the food's properties and nutritional content. The consumption of medicinal and aromatic herbs in Mexico is traditional and widespread. In this work, an analysis of an indirect solar dryer's thermal behavior was carried out with the coupling of solar technologies (water heaters and air collectors and photovoltaic pumping as an aid to the generation of hot air) comparing with electric oven drying in Campeche, Campeche, Mexico. The experimental results showed that the indirect tunnel type dryer that works with evacuated tubes and solar air heater simultaneously is the most efficient technology, with average drying times of $300 \mathrm{~min}$ and final humidity of $9.6 \%$. A study of colorimetry, water activity, and drying speed was carried out to control the drying process. It was found that it is possible to use solar energy to dry food as a means of conservation in warm-humid climates, also obtaining significant energy savings and contributing to caring for the environment.
\end{abstract}

\section{Keywords: Solar drying, Hybrid dryers, Drying kinetics, Solar technologies, Heat exchanger, Thermal characterization}

\section{Introduction}

Global energy demand is increasing dramatically, and, as a result, we are experiencing a reduction in conventional energy resources in an unprecedented way. There are presently various kinds of solar drying systems available to process agricultural products (Devan, Bibin, Asburris Shabrin, Gokulnath, \& Karthick, 2020). Solar drying is a promising and attractive application of solar energy systems. Solar dryers are classified into two main groups based on airflow mode: forced convection and natural convection solar dryers (Mewa, Okoth, Kunyanga, \& Rugiri, 2019). There are many disadvantages to the open sun traditional drying, which require a large surface area, long drying time, many contaminants, and low quality. Therefore, to reduce these disadvantages and obtain an acceptable dry dried product, it is essential to select an efficient drying system (Vengsungnle, Jongpluempiti, Srichat, Wiriyasart, \& Naphon, 2020).

\footnotetext{
| ${ }^{1}$ Facultad de Ingeniería, Universidad Autónoma de Campeche, Campus V, predio s/n por Av Humberto Lanz Cárdenas y Unidad Habitacional Ecológica ambiental, Col. Ex Hacienda Kalá, C.P. 24085, San Francisco de Campeche, Campeche, México

| ${ }^{2}$ Centro Universitario Del Norte, Universidad De Guadalajara. Carretera Federal No. 23, Km. 191, C.P. 46200, Colotlán, Jalisco, México
} 
The use of medicinal plants in Mexico has been practiced since pre-Hispanic times; these plants represent an effective remedy to cure different diseases, whether physical, psychosomatic, or magic-religious (Can Ortíz, Aguilar Cordero, \& Ruenes Morales, 2017). There are many publications on dehydration of different types of leaves of medicinal plants such as Artemisia absinthium, Thymus, salvia, Origanum vulgare, Lavandula, Moringa oleifera, and Mint. Peppermint (Mentha spicata) Is cultivated in different regions of the country due to its excellent culinary and agronomic characteristics. Among its benefits is that it resists the germs that produce foul odors in the oral cavity, giving the person a bit of freshness and menthol, it minimizes the symptoms of irritable bowel, gastric inflammation, excess gases, it is an antioxidant, among other properties (Alonso \& Desmarchelier, 2014).

\subsection{Solar Drying}

The application of solar drying techniques is currently prevalent. In the literature, there are essential publications worldwide on developments in the design and operation of solar dryers to reduce drying times by increasing their efficiency without sacrificing the quality of the final product: open sun drying, natural or forced convective drying (T., AlIsmaili, Janitha Jeewantha, \& Al-Habsi, 2019), photovoltaic-ventilated mixed-mode greenhouse solar dryer (Vengsungnle et al., 2020), (Chauhan, Kumar, \& Gupta, 2017), indirect type tunnel (Mewa et al., 2019), hybrid passive-mode and active-mode (Mohammed, Fatumah, \& Shadia, 2020), hybrid solar dryer coupling evacuated tube collectors, flat plate collectors, supported with electric fan heaters and the system for modulating the velocity field of the drying air (Pangavhane \& Sawhney, 2002).

\subsection{Solar Drying Menta spicata leaves}

In the literature, a study was found of drying mint spicata leaves in a tunnel-type solar dryer. An indirect forced convection solar dryer consisting of an air flat plate collector and a drying cabin was designed and fabricated to investigate its performance under Algiers' climate. Drying experiments have been performed for spearmint leaves at different airflow rates to determine the drying velocity, the characteristic drying curve, the effective diffusion coefficient, and the activation energy (Nour-Eddine, Belkacem, \& Abdellah, 2015). Another article was found to determine the effects of microwave power density on drying time and drying rate, improve product quality in terms of color and compare the adjustability of various drying equations to express the leaf drying kinetics with the most suitable model (Soysal, 2005). Because these two studies analyze the drying of Mentha spicata, with the same drying technologies with which it has experimented in the present work, they are taken as a reference during the development and conclusions presented.

\section{Experimental Study}

The study presented the process of drying the Mentha spicata L., an indirect solar dryer and an electric oven with the controlled temperature at $55^{\circ} \mathrm{C}$ since the plants are regularly dried in ovens; In this way, it is intended to make a comparative, to determine the viability of solar drying in hot-humid climates such as Campeche, Mexico, by implementing various thermal solar technologies, to support the dragging of dry air into the chamber drying. 


\subsection{Materials and Methods}

Raw material. Fresh Mentha spicata leaves were cut directly from the plants grown in Campeche, Mexico; they were selected for the sampling with which they have experimented, based on size thickness, thickness, and weight, to work with volumes similar samples. The leaves were washed, dried, weighed, and placed inside the solar dryer and oven.

\section{Experimental methods.}

Solar dryer tunnel. The indirect solar dryer has a rectangular shape and comprises three cabinets, and each one has an independent door. Also, each cabinet has two trays in which the food to be dried is placed. The trays are made of galvanized mesh, and the separation between them is $20 \mathrm{~cm}$. Neoprene rubbers hermetically seal the indirect solar dryer. The drying chamber measurements are $1.5 \mathrm{~m}$ long, $60 \mathrm{~cm}$ wide, and $60 \mathrm{~cm}$ high. Figure 1 shows the technical specifications of this solar dryer.

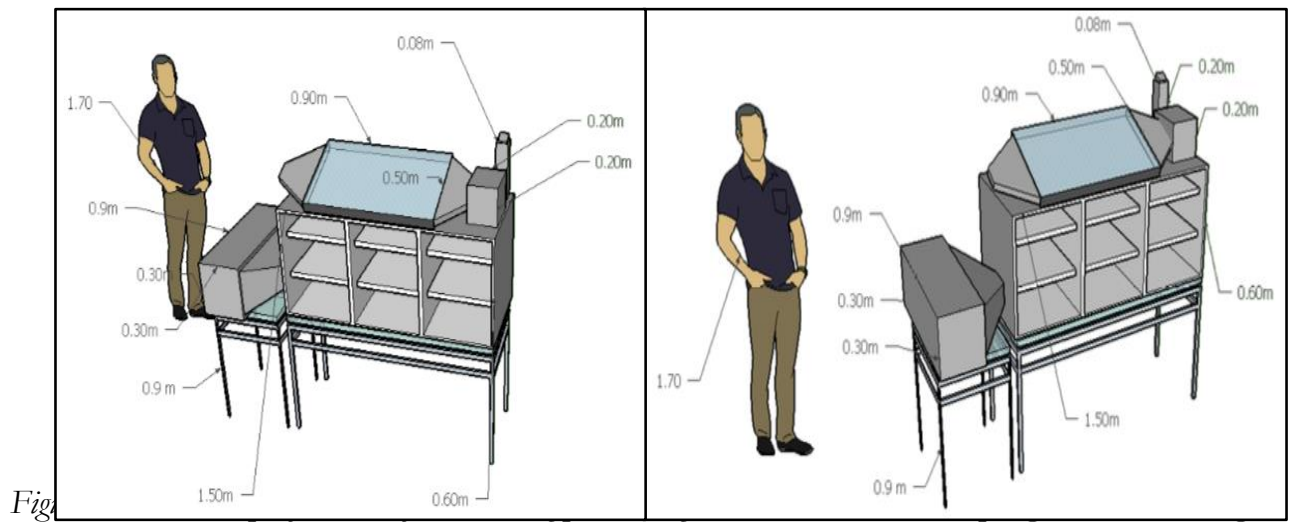

The drying chamber, connected to an evacuated solar tube, uses a hopper. This hopper drives preheater air inside, applying a heat exchanger covered with a metal box (figure 2a). The dryer has a solar air collector installed at the top (figure 2-b); this collector connected to a fan, extracts the ambient air to the dryer chamber interior, increasing its temperature (figure 2-c). Additionally, the dryer has a chimney for the exit of saturated air, with an inclination of $5 \mathrm{~cm}$ to escape air.

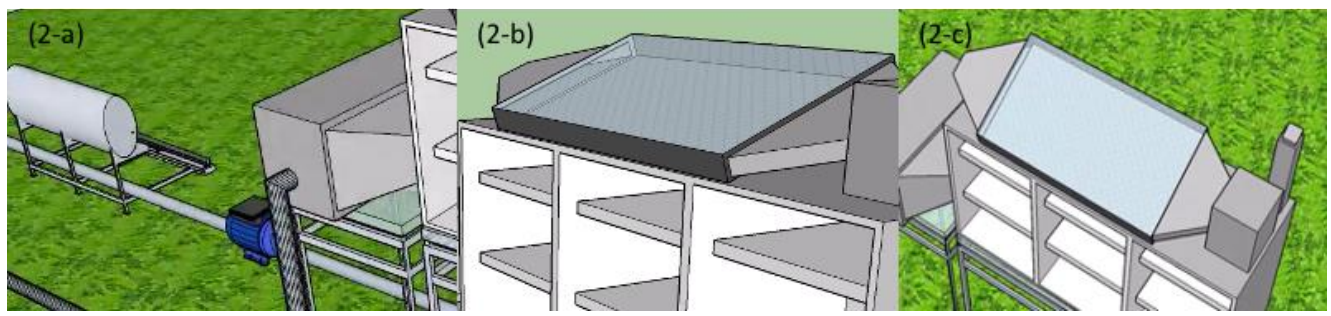

Figure 2. Diagram of the indirect solar dryer and its components 
Figure 3 shows the tunnel type solar dryer in real operating conditions.

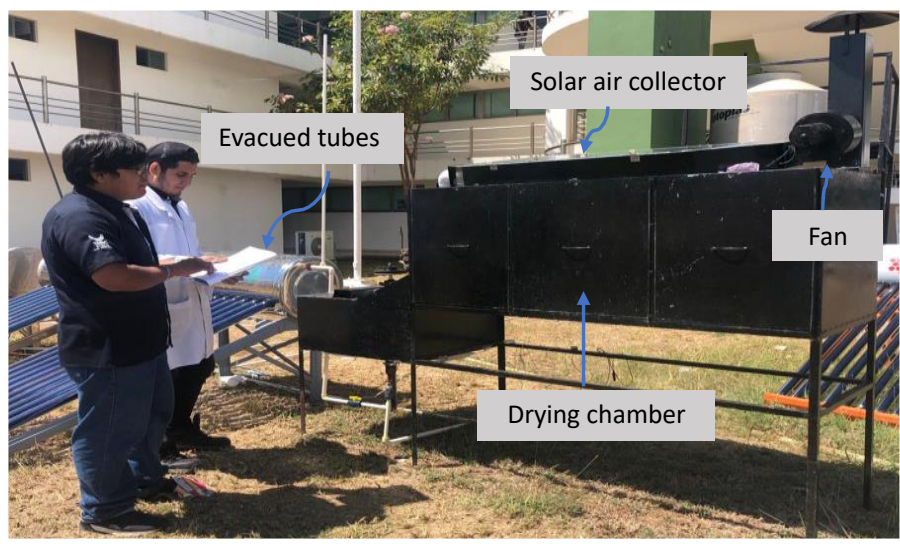

Figure 3. Indirect solar dryer with solar collector coupling and heat exchanger

Electric Oven. The oven that was used to dry the leaves is electric and without forced convection, Riossa brand. Throughout the process, samples of the weight loss were taken every $30 \mathrm{~min}$ to different temperatures until the final drying kinetics were obtained. The best results obtained $\left(55^{\circ} \mathrm{C}\right)$ are presented in this study.

\subsection{Instrumentation}

The loss of moisture in the leaves during the drying process was controlled in both technologies using a Boeco BMA150 brand moisture loss balance, precision of \pm 1 $\mathrm{mg}(0.001 \%)$. The water activity in the fresh and dried leaves was measured using a balance of the Aw brand, Rotronic HygroPalm, precision of $\pm 0.01 \% \mathrm{mg}$. A thermohygrometer Brannan brand was used to control the temperature (accuracy $\pm 1{ }^{\circ} \mathrm{C}$ ), humidity (accuracy $\pm 3 \%$, and a bimetal sphere thermometers brand CEC-Instruments were used; these remained installed inside the drying chamber throughout the test period. During the drying process, the loss of mass in the leaves was weighed every $30 \mathrm{~min}$, until the weight stabilized, using a Boeco balance, model BPS40plus, (precision of $\pm 0.001 \mathrm{~g}$ ).

The Faculty of Engineering of the Universidad Autonoma de Campeche has installed a solarimetric station right on the platform where the solar dryers are being operated; it is essential to control the environmental data to correlate them with the experimental results. Table 1 shows the technical specifications of this equipment measurement.

Table 1. Specifications of the measuring instruments of the solarimetric station located in the Faculty of Engineering

\begin{tabular}{|l|l|l|}
\hline VARIABLE & DESCRIPTION & ACCURACY \\
\hline Global solar irradiance & LI-COR & $\begin{array}{l}\text { Azimuth: }< \pm 1 \% \text { on } \\
360^{\circ} \text { to } 45^{\circ} \text { of elevation }\end{array}$ \\
\hline Relative humidity & NRG Systems & $\pm 3 \%$ \\
\hline
\end{tabular}




\begin{tabular}{|l|l|l|}
\hline Ambient temperature & NRG Systems & $\pm 1.1^{\circ} \mathrm{C}$ \\
\hline Wind velocity and direction & NRG Systems & $\pm 3^{\circ}$ \\
& Wind sensor & $\pm 0.3 \mathrm{~m} / \mathrm{s}$ \\
\hline
\end{tabular}

\section{Results and Discussion}

As mentioned above, the initial and final humidity percentage and water activity (Aw) was measured during leaf drying, and these results are presented in Table 2.

Table 2. Initial and final humidity and water activity were obtained by different drying methods (average).

\begin{tabular}{|c|c|c|c|c|}
\hline \multirow{2}{*}{ Technology } & \multicolumn{2}{|c|}{ Humidity (\%) } & \multicolumn{2}{|c|}{ Water activity (aw) } \\
\hline & Initial & Final & Initial & Final \\
\hline Oven $\left(55^{\circ} \mathrm{C}\right)$ & 82 & 4 & 0.85 & 0.2 \\
\hline Indirect solar dryer & 80 & 11 & 0.9 & 0.4 \\
\hline
\end{tabular}

It is important to note that the data obtained on the percentage of final humidity and final water activity can ensure that dry leaves are not susceptible to fungi or bacteria.

\subsection{Ambient conditions}

The data measured by the solarimetric station, taking as an example a test day (a sunny day was selected), are the next: the maximum irradiance reached on this day was 952 $\mathrm{W} / \mathrm{m}^{2}$. While for the ambient temperature, the average varied between $30^{\circ} \mathrm{C}$ and $33{ }^{\circ} \mathrm{C}$. The minimum relative humidity measured was $44 \%$, and the maximum was $81 \%$ (figure 4).

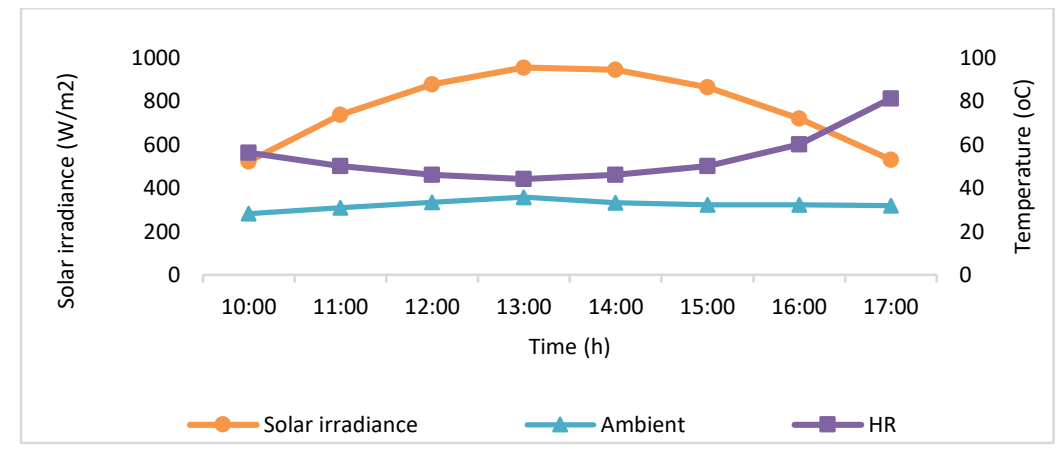

Figure 4. Ambient conditions on a select day during the test period

\subsection{Thermal characterization of solar dryer}

Figures 5 shows the effect of solar irradiation and the ambient temperature of the solar dryer working with solar heaters, and figure 6 shows the temperature reached by the water circulating in the evacuated tubes and the solar irradiance, with the idea of observing its effect on the temperatures reached in the drying chamber. The figures are denoted as "entry, in middle and final" each of these sections. 


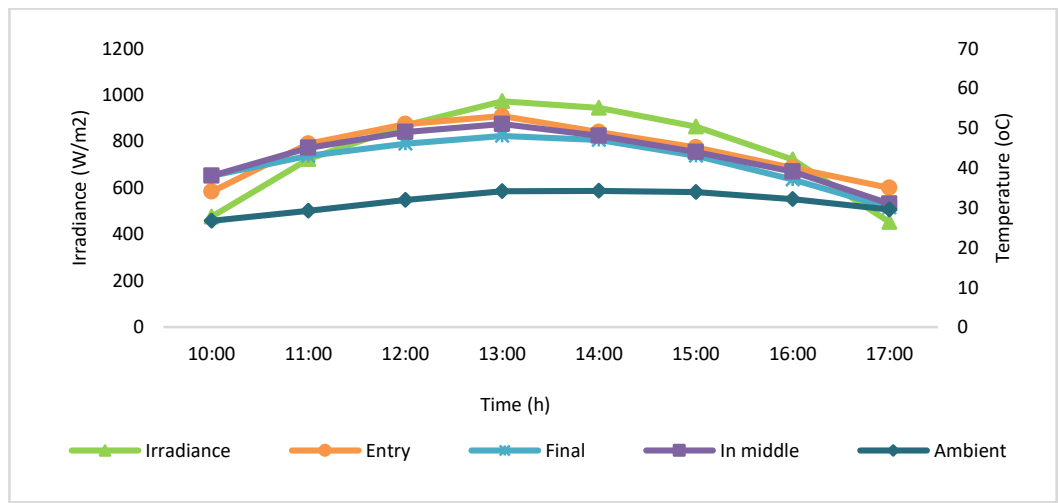

Figure 5. Comparison of ambient dates and temperatures reached in the indirect solar dryer operating with solar heaters and solar air collector.

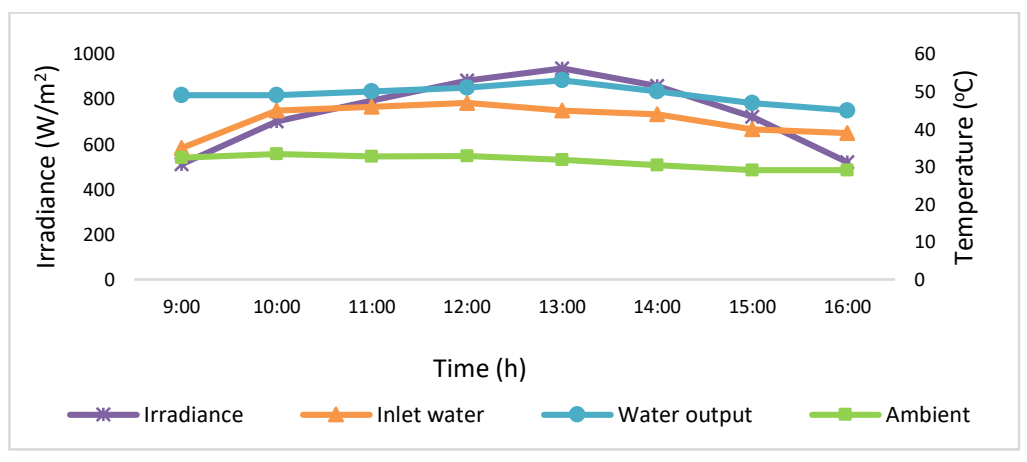

Figure 6. Temperatures measured in the water circulating in the evacuated tubes

The temperature of the evacuated tube's supply water (inlet) and its outlet temperature can be analyzed. As can be seen, the maximum temperature reached is $53^{\circ} \mathrm{C}$ at $1 \mathrm{pm}$, with solar irradiation of $936.5 \mathrm{~W} / \mathrm{m}^{2}$. It is essential to see that the temperature entering the evacuated tubes is very comparable to the environment's temperature at the beginning of the day. As solar radiation increases, this temperature also increases because the pipe that leads the water is copper, which helps the preheated water enter the system.

Figure 7 shows that the air collector's temperature behaves similarly to that of solar irradiation, reaching the maximum temperature of $57.1^{\circ} \mathrm{C}$ at $1: 00 \mathrm{pm}$, the maximum average temperatures reached during the test period varied between $49.2^{\circ} \mathrm{C}$ and $52.2^{\circ} \mathrm{C}$. 


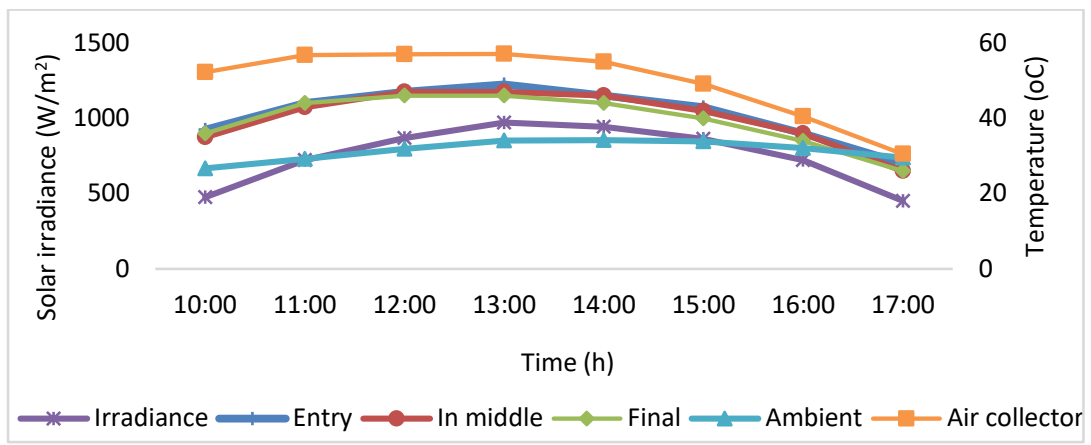

Figure 7. Temperature measured inside of the air collector and the indirect dryer compared to solar irradiation

The hot air propelled into the drying chamber through the air collector has an average velocity of $2.8 \mathrm{~m} / \mathrm{s}$, which was kept constant inside the dryer; in this case, the maximum temperature measured in the dryer reached $50{ }^{\circ} \mathrm{C}$ at 1:00 pm.

The highest temperature in the dryer was achieved using both evacuated tubes and solar air collectors. The first section (the preheated air intake area from both the solar water heater and the air collector) reaches a higher temperature $\left(51^{\circ} \mathrm{C}\right)$. However, temperatures have low variation; the three cases' temperatures are between $48{ }^{\circ} \mathrm{C}$ and $51{ }^{\circ} \mathrm{C}$ (Figure 6 ).

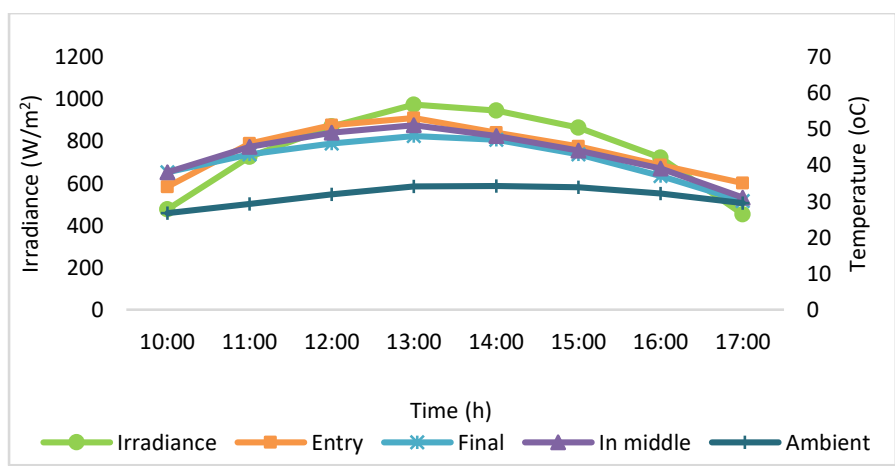

Figure 6. Comparison of climatic parameters and temperatures reached in the indirect solar dryer working with evacuated tubes and solar air heater, one sunny day during the test period

\subsection{Drying kinetics.}

Tests were carried out in the oven at different temperatures in a range of $40^{\circ} \mathrm{C}$ $60{ }^{\circ} \mathrm{C}, 10 \mathrm{~g}$ of fresh leaves were introduced in each experiment. In this study, the best drying results are presented, which were $55^{\circ} \mathrm{C}$. In the solar dryer, the dried leaves had a final average weight of $2.63 \mathrm{~g}$, and in the oven, $2.83 \mathrm{~g}$. Figure 7 shows the behavior of the dry moisture content obtained in the two case studies. In the indirect dryer case, the drying time was 300 minutes, with a final moisture content of $0.309 \mathrm{~g}$ of water/g of dry matter. The drying time was 250 minutes with the oven, and the final moisture content was 0.87 $\mathrm{g}$ of water/g of dry matter. 


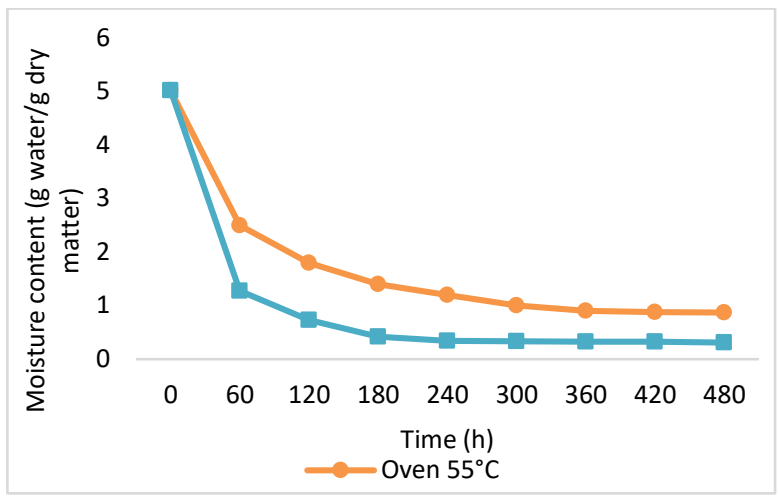

Figure 7. Moisture content concerning the drying time in oven at and $55^{\circ} \mathrm{C}$ and indirect solar dryer.

Data obtained in this study with indirect tunnel-type solar dryer technology, with a solar air collector coupling, agree with those obtained in a previous study: Mentha spicata leaf in the temperature $40{ }^{\circ} \mathrm{C}-50{ }^{\circ} \mathrm{C}$, under the same conditions, the difference is, in this study above an electrical heater was used as an auxiliary source our-Eddine (Nour-Eddine et al., 2015).

\subsection{Colorimetric study}

Table 3 shows the results of $\triangle \mathrm{E}$ (represents the color difference in the samples), obtained in the study of colorimetry performed on Mentha spicata leaves (Mendoza, Dejmek, \& Aguilera, 2006):

$$
\Delta E=\llbracket\left(\Delta L^{2}\right)+\left(\Delta a^{2}\right)+\left(\Delta b^{2} \rrbracket^{1 / 2}\right.
$$

The three colorimetry parameters measured are luminosity (L), redness (a), and yellowness (b). The value of $\mathrm{L}$ varies from 100 (for perfect white) to 0 (for black) (Doymaz \& Pala, 2002).

Tabla 3. The color difference obtained in drying leaves compared to drying time

\begin{tabular}{|l|l|l|l|l|l|}
\hline \multirow{2}{*}{ Dryer operation mode } & \multicolumn{5}{|l|}{ DRY LEA VES } \\
\cline { 2 - 6 } & $\Delta \mathbf{E}$ & Time & L* $^{*}$ & $\mathbf{a}^{*}$ & $\mathrm{~b}^{*}$ \\
\hline Tunnel type & 13.71 & 300 & 40.64 & -1.31 & 14.44 \\
\hline Oven 55 ${ }^{\circ} \mathbf{C}$ & 7.35 & 250 & 41.51 & 1.46 & 22.26 \\
\hline
\end{tabular}

The parameter $\mathrm{a}^{*}$ shows a significant increase, which reveals a trend towards reddish colors and, therefore, a decrease in green color, which is reflected in the $\Delta \mathrm{E}$ results. However, the results obtained indicate that in the case of the conservation of the green color in both solar dryer and oven was very remarkable compared to other drying technologies, but the oven conserved more this color. In the case of the $\mathrm{b}^{*}$, in both cases, this value decreased; this indicates a trend towards gray colors. 


\section{Conclusions}

The drying time in an electric oven at $55^{\circ} \mathrm{C}$ was 250 minutes. The drying times obtained in the indirect solar dryer was 300 minutes, on average. As can be seen, the drying times are similar in both cases. However, conventional electric energy is not used with the solar dryer, yet it is a significant challenge to achieve concerning the color care obtained in the electric oven; still, the solar dryer meets commercial requirements and maintains the dried leaves' color. The experimental results were obtained to promote solar energy for the medicinal plants since we reach an acceptable quality, supporting in avoiding the use of conventional energy and encouraging renewable energy to increase.

\section{References}

Alonso, J., \& Desmarchelier, C. (2014). Plantas Medicinales Autoctonas de la Argentina. Bases Científicas para su aplicacion en atencion primaria de la salud. Corpus.

Can Ortíz, G. O., Aguilar Cordero, W. de J., \& Ruenes Morales, R. (2017). Médicos tradicionales mayas y el uso de plantas medicinales, un conocimiento cultural que continúa vigente en el municipio de Tzucacab, Yucatán, México. Teoría y Praxis, 13(21), 67-89. https://doi.org/10.22403/uqroomx/typ21/04

Chauhan, P. S., Kumar, A., \& Gupta, B. (2017). A review on thermal models for greenhouse dryers. Renewable and Sustainable Energy Reviews, 75(August), 548-558. https://doi.org/10.1016/j.rser.2016.11.023

Devan, P. K., Bibin, C., Asburris Shabrin, I., Gokulnath, R., \& Karthick, D. (2020). Solar drying of fruits - A comprehensive review. Materials Today: Proceedings, (xxxx). https://doi.org/10.1016/j.matpr.2020.04.041

Doymaz, I., \& Pala, M. (2002). Hot-air drying characteristics of red pepper. Journal of Food Engineering, 55(4), 331-335. https://doi.org/10.1016/S0260-8774(02)00110-3

Mendoza, F., Dejmek, P., \& Aguilera, J. M. (2006). Calibrated color measurements of agricultural foods using image analysis. Postharvest Biology and Technology, 41(3), 285-295. https://doi.org/10.1016/j.postharvbio.2006.04.004

Mewa, E. A., Okoth, M. W., Kunyanga, C. N., \& Rugiri, M. N. (2019). Experimental evaluation of beef drying kinetics in a solar tunnel dryer. Renewable Energy, 235-241. https://doi.org/10.1016/j.renene.2019.02.067

Mohammed, S., Fatumah, N., \& Shadia, N. (2020). Drying performance and economic analysis of novel hybrid passive-mode and active-mode solar dryers for drying fruits in East Africa. Journal of Stored Products Research, 88, 101634. https://doi.org/10.1016/j.jspr.2020.101634

Nour-Eddine, B., Belkacem, Z., \& Abdellah, K. (2015). Experimental study and simulation of a solar dryer for spearmint leaves (Mentha spicata). International Journal of Ambient Energy, 36(2), 50-61. https://doi.org/10.1080/01430750.2013.820149

Pangavhane, D. R., \& Sawhney, R. L. (2002). Review of research and development work on solar dryers for grape drying. Energy Conversion and Management, 43(1), 45-61. https://doi.org/10.1016/S0196-8904(01)000061

Soysal, Y. (2005). Mathematical modeling and evaluation of microwave drying kinetics of mint (Mentha spicata L.). Journal of Applied Sciences.

T., S., Al-Ismaili, A. M., Janitha Jeewantha, L. H., \& Al-Habsi, N. A. (2019). Effect of solar drying methods on color kinetics and texture of dates. Food and Bioproducts Processing, 116, 227-239. https://doi.org/10.1016/j.fbp.2019.03.012

Vengsungnle, P., Jongpluempiti, J., Srichat, A., Wiriyasart, S., \& Naphon, P. (2020). Thermal performance of the photovoltaic-ventilated mixed mode greenhouse solar dryer with automatic closed loop control for Ganoderma drying. Case Studies in Thermal Engineering, 21(April), 100659. https://doi.org/10.1016/j.csite.2020.100659 